\title{
SACERDÓCIO FEMININO: A SANTA SÉ FRENTE AOS DESAFIOS CONTEMPORÂNEOS
}

\author{
Ana Cândida Vieira Henriques*
}

\begin{abstract}
RESUMO
A polêmica em torno da ordenação de mulheres ao sacerdócio católico é uma questão que traz, à luz da contemporaneidade, uma negação fundamentada in persona Christi Capitis. A escassez de sacerdotes, aliado à vontade de mulheres que almejam um papel relevante dentro da igreja, gera certa inquietação. Alguns esforços estão sendo concentrados pelo atual papado, visando uma maior infiltração da mulher no âmbito eclesiástico, mas apenas na condição de diaconisa. Nesses termos, pretendemos tratar de todas essas questões emergentes dentro de uma perspectiva analítico-crítica a partir das Ciências das Religiões. Como referencial teórico, utilizaremos dois documentos oficiais da igreja, o Código de Direito Canônico e a Encíclica Ordinatio Sacerdotalis, além da contribuição de estudiosos contemporâneos. Palavras-chave: Mulher. Sacerdócio. Santa Sé. Contemporaneidade. Ciências das Religiões.
\end{abstract}

\section{FEMALE PRIESTHOOD: THE HOLY SEE FACING THE CONTEMPORARY CHALLENGES}

\begin{abstract}
The controversy surrounding the ordination of women to the Catholic priesthood is a question that brings to light of the contemporaneousness, a denial founded in persona Christi Capitis. The shortage of priests coupled with the will of women who long for a relevant role within the church, generates a certain uneasiness. Some efforts are being concentrated by the present papacy, aiming for greater infiltration of the woman in ecclesiastical field, but only in condition of deaconess. In these terms, we intend to deal with all emergency questions within an analytical-critical perspective from the Sciences of Religions. As a theoretical reference, we will use two of official
\end{abstract}

* Doutoranda do Programa de Pós-Graduação em Ciências das Religiões (PPGCR - UFPB). 
documents of the Church, the Code of Canon Law and an Encyclicia Ordinatio Sacerdotalis, as well as contribution of contemporary scholars.

Keywords: Woman. Priesthood. Holy See. Contemporaneity. Sciences of Religions.

\section{SACERDOCIO FEMENINO: LA SANTA SÉ FRENTE A LOS DESAFÍOS CONTEMPORÁNEOS}

\section{RESUMEN}

La polémica en torno de la ordenación de mujeres al sacerdocio católico es una cuestión que trae, a la luz de la contemporaneidad, una negación fundamentada in persona Christi Capitis. La escasez de sacerdotes, aliado a la voluntad de mujeres que anhelan un papel relevante dentro de la iglesia, genera cierta inquietud. Algunos esfuerzos están siendo concentrados por el actual papado, buscando una mayor infiltración de la mujer en el ámbito eclesiástico, pero sólo en la condición de diaconisa. En estos términos, pretendemos tratar de todas estas cuestiones emergentes dentro de una perspectiva analítico-crítica a partir de las Ciencias de las Religiones. Como referencial teórico, utilizaremos dos documentos oficiales de la iglesia, el Código de Derecho Canónico y la Encíclica Ordinatio Sacerdotalis, además de la contribución de estudiosos contemporáneos.

Palabras clave: Mujer. Sacerdocio. Santa Sede. Contemporaneidad. Ciencias de las Religiones.

\section{INTRODUÇÃO}

Neste artigo, consideramos emergente e necessário tratarmos de questões respeitantes à participação feminina no âmbito eclesiástico da Igreja Católica Romana. Desde tempos imemoriais, a presença da mulher insurge na história religiosa com certo dinamismo, quando nos deparamos com as inúmeras narrativas mitológicas que trazem em seus conteúdos, o feminino atuando em seu espaço. Apesar dos grandes obstáculos à liberdade de inserção da mulher no meio confessional, vários segmentos da sociedade civil se empenham em abrir caminhos, mesmo que ainda tortuosos.

A emblemática questão da ordenação de mulheres ao sacerdócio cristão católico romano, gera debates polêmicos de ambas as correntes, sejam a favor ou contra esse processo de cunho sacramental. A igreja 
contemporânea, seguindo o mesmo caminho da igreja dos primeiros séculos, veda essa prerrogativa fundamentada em seus documentos doutrinais jurídicos, principalmente no Código de Direito Canônico. A vedação ao sacerdócio feminino tem caráter definitivo legitimado na Carta Apostólica Ordinatio Sacerdotalis, do papa João Paulo II. Essa impossibilidade está sumariamente situada nas funções de episcopado, presbiterado e diaconado, ${ }^{1}$ contudo, esta última função está sendo minuciosamente averiguada por uma comissão formada pelo atual papado, o que posteriormente pode ser colocada à disposição, ou não, ao ingresso de mulheres.

Na condição de diaconisa, a mulher estaria apta "para o serviço", mas não "para o sacerdócio", pois que o diaconado é direcionado para uma função assistencial junto aos bispos e padres (CNBB, 2000, p. 430). A escassez de padres é uma realidade que assola a igreja de Roma. Esse indicativo pode viabilizar a realização de um anseio feminino, representado por uma vontade de servir mais intensamente a Deus. Recentemente o papa Francisco sinalizou certa abertura quando se propõe a analisar essa possibilidade. Agora nos resta esperar para ver.

Nesses termos, numa perspectiva analítico-crítica e a partir do observatório das Ciências das Religiões, traremos em um primeiro momento, um breve percurso da mulher na história religiosa, ressaltando a sacralidade do princípio feminino, seja por meio das mitologias - como deusas e mulheres humanas que geraram semideuses - seja por intermédio do profetismo desempenhado num dado momento da História. Em seguida, para compreendermos a concepção de mulher na teologia cristã, nos concentraremos brevemente no seu papel e na sua condição vivida no nascimento da religião. E, por fim, veremos os fundamentos doutrinais onde estão as cláusulas que justificam a não aceitação de mulheres ao sacerdócio, ao mesmo tempo, evidenciando uma realidade contemporânea que a igreja vem enfrentando devido a essa negação.

Ao diaconado (ou diaconato), cabe, "entre outros serviços, assistir o Bispo e os padres na celebração dos divinos mistérios, sobretudo a Eucaristia, distribuir a Comunhão, assistir ao Matrimônio e abençoá-lo, proclamar o Evangelho e pregar, presidir os funerais e consagrar-se aos diversos serviços da caridade", contudo, o diácono não é sacerdote. Ver CNBB, 2000, p. 430. 


\section{A SACRALIDADE FEMININA NA RELIGIÃO}

A história religiosa, por meio de suas mitologias, foi e ainda é fortemente marcada pela presença do feminino. Os cultos de fertilidade, tão característicos das religiões naturistas asiânicas, rendem votos à conjunção hierogâmica dos princípios masculino e feminino como sinal de fecundação terrena. A celebração do casamento sagrado entre o casal de deuses - o céu e a terra - gera para o ser humano, a fecundidade e a fertilidade necessárias para a sua sobrevivência. Da união entre os deuses babilônicos Marduk e Aruru, nasceram os homens que povoaram a terra, as florestas e também os animais (Étienne DRIOTON et al., 1958, p. 65, 95).

No Egito antigo, as divindades locais eram em grande número, e muitas delas eram deusas femininas, cujas funções complementavam as funções dos deuses masculinos, e algumas vezes tinham a função até de protegê-los, como é o caso de Isis. A deusa egípcia Isis foi uma das principais divindades femininas, ela era esposa do deus Osíris e mãe do deus Hórus, e tinha uma função dentro do panteão, de proteger Osíris, seu companheiro (Étienne DRIOTON et al., 1958, p. 18). Na maioria das vezes, essas deusas eram esposas, mães e/ou filhas dos deuses masculinos. ${ }^{2}$ É interessante percebermos a importância do princípio feminino dentro da religião através das mitologias. Desde sua origem, a religião foi enriquecida pelos inúmeros mitos que a compõem. Os mitos, assim como a experiência religiosa, se constituem como sustentáculos, pois vivificam a religião.

A maioria dos mitos cosmogônicos relata o surgimento do cosmo como "resultado de uma hierogamia entre o Deus-Céu e a Terra-Mãe" (Mircea ELIADE, 2010, p. 121). De acordo com Eliade, a mulher está relacionada misticamente à terra, "a sacralidade da mulher depende da santidade da terra. A fecundidade feminina tem um modelo cósmico: o da Terra Mater, da mãe universal" (Mircea ELIADE, 2010, p. 120-121). Nesse sentido, a mulher está mais intimamente ligada à natureza, e esse vínculo natural adquire uma forte representação quando ela está estruturada simbolicamente como aquela que está "mais perto da na-

A exemplo de Maet, filha de Ra; Mut, esposa de Amon e mãe de Khonsu; Néftis, esposa de Set e mãe de Anúbis; Sekhmet, esposa de Ptah e mãe de Nefertum, entre outras. 
tureza" - closer to nature (Rosemary Radford RUETHER, 1983, p. 72). Diante disso, não podemos relegar a segundo plano o papel e a ligação da mulher com os mitos de criação e com a própria natureza, pois a presença do feminino é imprescindível para a complementaridade com seu oposto, o masculino.

Nas inúmeras mitologias ${ }^{3}$ pagãs dos deuses e heróis - grega, romana, oriental, entre outras - encontramos vários relatos sobre a concepção de seres considerados semideuses, isto é, seres que provavelmente foram concebidos por pais humanos e divinos. Temos várias narrativas mitológicas, nas quais situamos a história de Hércules, Aquiles, Perseu, Eneias, e muitos outros. Nessas narrativas, Hércules teria nascido da união de um deus com uma mãe humana (Júpiter [para os romanos] / Zeus [para os gregos] e Alcmena). Já Aquiles nasceria de pai humano, Peleu e mãe divina, Tétis; Perseu, por sua vez, era filho de Júpiter e Dânae, pai divino e mãe humana; e Eneias também teria nascido de uma união humana e divina, ele era filho do troiano Anquises e da deusa grega Afrodite. Vemos aqui que esses semideuses, considerados heróis pela mitologia, eram filhos de pais de naturezas distintas, humanos/divinos e mortais/imortais (Thomas BULFINCH, 2006, p. 121, 144, 210, 249). Queremos destacar aqui, mais uma vez, a indispensável presença do feminino nas histórias mitológicas, exercendo uma função essencial de gerar a vida de seres humanos, dotados de atributos considerados divinos. Apenas o princípio feminino possui a prerrogativa de gerar, de gestar e de conceber, seja no aspecto humano como mulher, seja no divino como deusa.

A atuação feminina na antiguidade, desde a era pré-clássica também vai moldar e introduzir mudanças de comportamento, principalmente de cunho religioso - apesar das fortes resistências masculinas nos vários contextos históricos - no que diz respeito aos seus diversos saberes,

De acordo com Bulfinch (2006, p. 287-290), a origem da mitologia está relacionada à algumas teorias, sendo elas, a Teoria bíblica, que diz que sua origem está nas narrativas das Escrituras; a Teoria histórica, para a qual todos os personagens das narrativas foram seres humanos reais; a Teoria alegórica, na qual todos os mitos são simbólicos, "contendo alguma verdade moral, religiosa ou filosófica, ou algum fato histórico, sob a forma de alegoria"; e a Teoria física, para a qual os elementos naturais (ar, fogo e água) "foram, originalmente, objetos de adoração religiosa, e as principais divindades eram personificações das forças da natureza". 
a exemplo do conhecimento da arte divinatória e do conhecimento da natureza para fins de cura. Aludimos para as sibilas, ${ }^{4}$ como poderíamos atinar também para o forte misticismo entranhado nas mulheres daquele tempo. As profecias também faziam parte do universo feminino com substancial intensidade. As dez sibilas desempenhavam um papel relevante naquela época, pois que faziam previsões para as diversas regiões, tendo chegado até a profetizar ao mundo greco-latino, a encarnação do Cristo como última profecia (Colette BEAUNE, 2006, p. 87).

Não podemos esquecer da grande deusa-mãe do neolítico, ${ }^{5}$ cuja função sagrada inspirava provavelmente cultos de fertilidade, configurando-se como um ser supremo feminino, que garantia a fertilidade da terra (Paolo SCAPI, 2004, p. 20,22). Basta saber que a mais antiga imagem - como representação - humana do divino (desde o paleolítico) era do sexo feminino (Rosemary Radford RUETHER, 1983, p. 47). Nesses termos, nos exemplos citados, tentamos situar o protagonismo e a função feminina em diferentes contextos da história religiosa. É oportuno acompanhar essa evolução ao longo do tempo sob a égide da religião e da espiritualidade. Sem dúvida, tais relatos e fatos só constatam a importância da mulher nos seus multi-aspectos inerentes à sua condição.

\section{A MULHER NA TEOLOGIA CRISTÃ}

Iniciaremos pela gênese da escritura cristã, o Antigo Testamento ou Antiga Aliança, ${ }^{6}$ o qual traz em sua narrativa poética a criação do

4 As sibilas eram mulheres conhecidas pelo dom de prever o futuro, de profetizar. Desde a Grécia pré-clássica, a fama dessas mulheres espalhou-se por toda a bacia do Mediterrâneo. A crença da época apontava que essas mulheres eram tomadas por um deus, daí sua inspiração divina e o vasto poder de adivinhação dos acontecimentos futuros. Uma lista contendo os nomes de dez mulheres profetisas (sibilas) foi criada pelo filósofo romano Varrão (116-27 a.C) e foi bastante difundida até a Idade Média (POTESTÁ E VIAN, 2013, p. 51).

5 Conforme achados arqueológicos em Çatal Hüyük (um dos maiores assentamentos neolíticos da Anatólia, datado entre 7.100 e 6.300 a.C), foi encontrado um número considerável de estatuetas femininas e umas poucas masculinas, denotando um provável culto de fertilidade, tutelado por uma grande deusa mãe. Essa aldeia - que já se utilizava de técnicas agrárias bem avançadas - possuía espaços distintos destinados a alguma função sagrada, nos quais essas estátuas femininas seriam objeto de culto. Como esse povo vivia do sustento da terra, isto é, da agricultura, essas imagens femininas podem remeter ao modelo histórico-religioso da Mãe Terra, como aquela que dá garantias de fertilidade (SCAPI, 2004, p. 19-22).

6 O Antigo Testamento relata a história e a aliança dos hebreus com Deus. 
universo e tudo que nele há. Nesse mito criacional, Javé Deus cria o cosmo e também o primeiro ser humano, o homem. A partir deste, se cria a mulher, ambos concebidos à imagem do Criador. Desse modo, o homem e a mulher foram constituídos como criaturas humanas, porém dotados de essência divina, pois foram criados a partir de uma vontade suprema sagrada. A criatura vai se caracterizar como um ser criado à imagem e semelhança do Criador, onde ambos são "iguais" para Javé Deus (CNBB, 1990, p. 14-15).

O Novo Testamento ou a Nova Aliança, é propriamente uma segunda parte da escritura cristã e traz, principalmente, o anúncio e ação da pessoa de Jesus Cristo. Neste, temos a narrativa de sua concepção e nascimento como marco de uma nova história. Jesus, filho de Deus e de Maria, uma mulher escolhida para gerar e conceber aquele que seria o fundamento do cristianismo. A importância do feminino na história religiosa cristã se consagra por intermédio da figura de Maria, mãe e mulher, que desempenhou o maior papel dentro dessa teologia como precursora e como a nova Eva.

Maria Madalena foi outra mulher que colaborou grandemente para a edificação do cristianismo, e principalmente, para o ministério de Jesus. Ela é chamada de "apóstola dos apóstolos", pois foi a primeira a presenciar o Cristo ressuscitado, quando anunciaria a boa nova aos apóstolos, o que posteriormente, eles anunciariam ao restante do mundo. De acordo com a Carta Apostólica Mulieris Dignitatem, esse fato vem corroborar com a forma que Jesus confiava as verdades divinas às mulheres, do mesmo modo que confiava aos homens. "Pode-se dizer que assim se cumpriram as palavras do profeta: "Derramarei o meu espírito sobre todo homem, e tornar-se-ão profetas os vossos filhos e as vossas filhas" $(\mathrm{J} 13,1){ }^{7}$

Assim como os outros apóstolos possuem um dia especial dedicado à sua memória na igreja, Maria Madalena também tem o seu dia. Por sua importância histórica dentro do cristianismo, o Vaticano reforçou seu status de santa, concedendo o 22 de julho como um dia dedicado àquela que foi uma das pessoas mais próximas de Jesus.

Ver João PAULO II, 1988. 
Se fôssemos elencar aqui as milhares de mulheres que tiveram uma grande participação desde o nascimento e desenvolvimento do cristianismo até os nossos dias, estaríamos nos submetendo a uma tarefa hercúlea, o que não convém, mas enfim, o importante é que a maioria deixou, indiscutivelmente, o seu legado. Quando nos enquadramos no contexto cristão dos primeiros séculos, notamos que, "no âmbito das comunidades, as mulheres desenvolviam funções diaconais reservadas a elas: assistência ao batismo [...], visitas pastorais e instruções religiosas, acolhimento e ordenamento das assembleias, viagens e visitas ao bispo" (Gian Luca POTESTÁ, Giovanni VIAN, 2013, p. 53). Como veremos mais adiante, o cristianismo primitivo, mais especificamente na pessoa de Paulo, acolhia muito bem as diaconisas, reconhecendo e recomendando seu trabalho dentro das comunidades mais carentes. Contudo, percebe-se que essas tarefas diaconais possuíam (e ainda têm) cunho assistencial, mesmo quando atuam na administração de um sacramento, como é o caso do batismo.

Nos primeiros séculos do cristianismo, surgiu uma seita cristã gnóstica chamada marcionismo, liderada por Marcião de Sínope. ${ }^{8}$ Este colocava as mulheres em condição de igualdade com os homens, nomeando-as diaconisas, sacerdotisas e até bispas, visto que era um paulinista radical, e seguia ao pé da letra um trecho específico da carta aos Gálatas $(3,28) .{ }^{9}$ Nesse período, a mulher gozava de certa importância e valorização dentro da igreja, vindo esse quadro mudar após a morte de Paulo (José María BLÁSQUEZ, 2010, p. 19-20).

Nessa época, embora houvesse uma aceitação, e até certo ponto, um reconhecimento do profetismo feminino, ${ }^{10}$ como igualmente ao diaconado, essa atuação não abriu portas, nem possibilitou, tampouco, adentrar nas camadas mais superficiais do ministério eclesial. Mas a gran-

8 Era teólogo, filho de um bispo do Ponto e fez parte da igreja primitiva entre 138 e 144 d.C., sendo afastado posteriormente por causa das suas ideias.

9 "Não há mais diferença entre judeu e grego, entre escravo e homem livre, entre homem e mulher, pois todos vocês são um só em Jesus Cristo". Ver CNBB, 1990, p. 1.428.

10 Paulo, em uma de suas cartas apostólicas, não só achava óbvio a possibilidade das mulheres profetizarem, como também reconhecia esse direito lhes imputado (Ver CNBB, 1990, p. 1.403; POTESTÁ E VIAN, p. 53; e KAUTSKY, p. 390-391). Também em CNBB (1990, p.1.359), Lucas se refere com naturalidade às quatro profetisas filhas de Filipe, em Cesareia. 
de questão, ao nosso ver, seria a própria condição da mulher naquela época, como ela era vista e concebida em relação ao homem. Para isso, pensamos ter nas cartas paulinas um meio de retratar, de certo modo, a condição feminina dentro de uma nascente cristã.

Quando Paulo diz, em Gálatas 3,28, que todos são iguais perante a lei divina, ele promove um nivelamento de natureza "espiritual", para além de qualquer hierarquização. Entretanto, quando vemos sua fala em outras cartas, essa igualdade fica apenas situada num plano espiritual, e não físico. Podemos conferir em várias passagens bíblicas, a exemplo da Primeira Carta a Timóteo, ${ }^{11}$ a Primeira aos Coríntios, ${ }^{12}$ aos Efésios, ${ }^{13}$ aos Colossenses, ${ }^{14}$ entre outras. Entretanto, de acordo com Karl KAUTSKY (2014, p. 391), os críticos bíblicos modernos, acreditam que várias passagens, ${ }^{15}$ e até cartas apostólicas inteiras, ${ }^{16}$ sofreram posteriormente um processo chamado "interpolação". Eles dizem se tratar de falsificação datada do século II, visando direcionar "a mulher novamente aos estreitos confins da família". Dessa forma, se essa hipótese se confirma, possivelmente a mensagem original de Jesus e de Paulo foram alteradas e distorcidas visando algum interesse religioso ou político.

Mas o fato é que, das catorze cartas atribuídas a Paulo, somente sete são seguramente imputadas a ele hoje. ${ }^{17}$ Os trechos bíblicos que nós já vimos referindo-se ao comportamento da mulher, fazem parte das

11 "Durante a instrução, a mulher deve ficar em silêncio, com toda a submissão. Eu não permito que a mulher ensine ou domine o homem. Portanto, que ela conserve o silêncio". CNBB, 1990, p. 1.461.

12 "Que as mulheres fiquem caladas nas assembleias, como se faz em todas as igrejas dos cristãos, pois não lhes é permitido tomar a palavra. Devem ficar submissas, como diz também a lei. Se desejam instruir-se sobre algum ponto, pergunte aos maridos em casa; não é conveniente que a mulher fale nas assembleias". IBID., p. 1.408.

13 "Mulheres, sejam submissas a seus maridos, como ao Senhor. E assim como a igreja está submissa a Cristo, assim também as mulheres sejam submissas em tudo aos maridos". IBID., p. 1.437.

14 "Mulheres, sejam submissas a seus maridos, pois assim convém a mulheres cristãs". IBID., p. 1.449 .

15 Primeira Carta aos Coríntios (1 Coríntios 14, 34-35).

16 Primeira e Segunda Carta a Timóteo (1 e 2 Timóteo) e também a Carta a Tito (Tito).

17 São elas: Primeira Carta aos Tessalonicenses, Primeira e Segunda Carta aos Coríntios, Carta a Filemon, e as Cartas aos Gálatas, aos Filipenses e aos Romanos. 
cartas cuja autoria ainda é objeto de discussão ${ }^{18}$ e outras, cujos autores foram discípulos mais ou menos próximos de Paulo. ${ }^{19} \mathrm{~A}$ décima quarta carta, que é a Carta aos Hebreus, possui autoria desconhecida, embora, tenha sido a primeira a despertar dúvidas sobre sua autoria (Gian Luca POTESTÁ; Giovanni VIAN, 2013, p. 17).

Esse pensamento e comportamento difuso e equivocado em relação à mulher, segue em via contrária aos ensinamentos e posturas adotados por Jesus, como podemos conferir na Mulieris Dignitatem, que trata sobre a dignidade e a vocação da mulher na igreja e na vida humana.

Em todo o ensinamento de Jesus, como também no seu comportamento, não se encontra nada que denote a discriminação, própria do seu tempo, da mulher. Ao contrário, as suas palavras e as suas obras exprimem sempre o respeito e a honra devidos à mulher. A mulher recurvada é chamada "filha de Abraão" (Lc 13,16), enquanto em toda a Bíblia o título "filho de Abraão" é atribuído só aos homens. [...] Este modo de falar às mulheres e sobre elas, assim como o modo de tratá-las, constitui uma clara "novidade" em relação aos costumes dominantes do tempo (João PAULO II, 1988).

No catecismo da igreja, o homem e a mulher são descritos como criaturas divinas "em perfeita igualdade como pessoas humanas" e "em idêntica dignidade à imagem de Deus", e que, portanto, em Deus não há "lugar para a diferença dos sexos", "por serem ao mesmo tempo iguais enquanto pessoas ("osso de meus ossos...") e complementares enquanto masculino e feminino" (CNBB, 2000, p. 106-107). De acordo com esse documento da igreja, o homem e a mulher são concebidos como seres iguais por Deus, contudo, distintos em suas funções de pai/ mãe e esposo/esposa.

Ainda na carta Mulieris Dignitatem, é citado um dos discursos do papa Paulo VI, o qual diz que, mais que em qualquer religião, a mulher na religião cristã sempre teve, desde as origens, sua dignidade reconhecida. Que ela "é destinada a fazer parte da estrutura viva e operante do cristianismo de modo tão relevante, que talvez ainda não tenham

18 São três: Segunda Carta aos Tessalonicenses, Efésios e Colossenses.

19 Também são três: Carta a Tito, Primeira e Segunda Carta a Timóteo. 
sido enucleadas todas as suas virtualidades". Pois bem, diante de tanto reconhecimento e igualdade contidos na doutrina cristã, como acabamos de ver, falta-lhes transformar tudo isso em ações práticas, dando um novo significado aos esforços empreendidos e o direito conquistado pelas mulheres nas últimas décadas.

\section{FUNDAMENTOS TEOLÓGICOS SOBRE O MINISTÉRIO SACERDOTAL FEMININO}

A grande polêmica em torno da ordenação de mulheres para a função de sacerdotisas gera debates atuais contundentes, porém pouco frutíferos em termos práticos, diante do forte posicionamento da igreja. Uma grande organização que se envolveu diretamente com essa questão foi a "Conferência para a Ordenação de Mulheres" (Women's Ordination Conference - WOC). Sua primeira conferência ocorreu em 1975, nos Estados Unidos, tornando-se a WOC no ano seguinte (1976), uma organização oficial empenhada na ordenação de mulheres em todos os ministérios da Igreja (Penelope J. RYAN, 1999, p. 68). Seguindo essa direção, outro organismo estadunidense que milita em favor dessa causa é o National Catholic Reporter, jornal norte-americano de referência e site extremamente popular, que faz parte da imprensa cristã dos Estados Unidos. Este acredita que a exclusão de mulheres ao sacerdócio não possui qualquer base de sustentação na escritura cristã, e que representa, de certa forma, uma injustiça para com as mesmas. O jornal reconhece, nas conclusões de 1976, da Pontifícia Comissão Bíblica, ${ }^{20}$ uma justificativa plausível para as suas inferências. Segundo o jornal, a maioria dos membros dessa comissão concluiu que as mulheres poderiam ser ordenadas sacerdotisas, pois que, isso não representaria ser contrário às "intenções originais de Cristo". ${ }^{21}$

20 Essa organização foi estabelecida pelo papa Leão XIII, por meio da Carta Apostólica Vigilantiae studiique, de 30 outubro de 1902. Foi conferido a essa comissão amplos poderes em relação às questões emergentes e disputas bíblicas, causadas pelos críticos modernos. Ver http://www. vatican.va/roman_curia/congregations/cfaith/pcb_documents/rc_con_cfaith_pro_14071997_pcbible po.html

${ }^{21}$ Informações extraídas do site do Instituto Humanitas Unisinos sobre o editorial do Jornal National Catholic Reporter, do dia 03-12-2012, sob o título "A ordenação de mulheres corrigiria uma injustiça". Ver http://www.ihu.unisinos.br/noticias/516324. 
Entretanto, a Declaração Inter Insigniores, ${ }^{22}$ aprovada em 15 de outubro de 1976, ${ }^{23}$ ressaltava que a "Sagrada Congregação para a Doutrina da Fé" reputa ser seu dever recordar que a Igreja, por um motivo de fidelidade ao exemplo do seu Senhor, não se considera autorizada a admitir as mulheres à ordenação sacerdotal". ${ }^{24}$ Essa assertiva, além de ter um fundamento teológico, tem também uma justificativa na própria tradição, como veremos a seguir.

A Igreja Católica nunca admitiu que as mulheres pudessem receber validamente a ordenação presbiteral ou episcopal. Algumas seitas heréticas dos primeiros séculos, sobretudo gnósticas, pretenderam fazer exercer o ministério sacerdotal por mulheres: uma tal inovação foi imediatamente observada e censurada pelos Padres, que a consideraram inaceitável na Igreja (CONGREGAÇÃO PARA A DOUTRINA DA FÉ, 1976).

Nesse sentido, a declaração dada pela igreja não se refere à ordenação diaconal, nos levando a crer que essas ordenações poderiam ter acontecido realmente. O teólogo norte-americano Gary Macy diz que as ordenações diaconais femininas, de fato, aconteceram até fim do século XII e início do século XIII. ${ }^{25}$ Macy, no entanto, esclarece que é necessário levar em conta que a compreensão de ordenação nesse período era bem diferente da compreensão dos séculos posteriores, assim como a própria acepção da palavra ordo, ordinatio e ordinare,

22 Essa declaração trata sobre a questão da admissão de mulheres ao sacerdócio ministerial.

23 Esse documento da igreja viria como uma reação do Vaticano ao empenho da WOC quanto à ordenação de mulheres (note-se que foi no mesmo ano em que esta se tornava uma organização de representatividade nacional). Na época, a WOC tinha à frente como primeira presidente, Ruth Fitzpatrick.

24 Ver http://www.vatican.va/roman_curia/congregations/cfaith/documents/rc_con_cfaith_ doc_19761015_inter-insigniores_po.html

25 Essa declaração baseia-se principalmente nos ritos de ordenação, pois, segundo o teólogo, esses são os indícios mais evidentes desta prática, estando contidos em vários documentos da igreja, a exemplo do sacramentário gregoriano do século IX. Ele ainda enfatiza que alguns papas e bispos fizeram referência a mulheres ordenadas, como o papa Bento VIII (1.018) e o bispo de Limerick (1.070-1.145). Entrevista concedida a Márcia Junges em $1^{\circ}$ de junho de 2009. Ver http://www.ihuonline.unisinos.br/index.php?option=com_content\&view=article\&id=2596\& secao $=295$. 
${ }^{26}$ que possuíam sentidos distintos nos vários contextos históricos. Seguindo essa linha, a teóloga norte-americana Phyllis Zagano também atesta a historicidade dessas ordenações diaconais femininas, e vai além quando acrescenta que ainda hoje mulheres são ordenadas como diaconisas em alguns lugares no Oriente. ${ }^{27}$

Vemos também na carta apostólica aos Romanos fortes indícios da prática da ordenação de mulheres quando Paulo se refere a uma mulher chamada Febe, a qual atua na condição de diaconisa dentro da igreja. Ele diz: "Recomendo a vocês nossa irmã Febe, diaconisa da igreja de Cencréia. Recebam-na no Senhor, como convém a cristãos. Deem a ela toda a ajuda que precisar, pois ela tem ajudado muita gente e a mim também" (CNBB, 1990, p. 1.392). Isso torna evidente, que na igreja primitiva, a mulher já desempenhava um importante papel ministerial, apesar de estar inserida num contexto fortemente marcado pela distinção de gênero proveniente dos séculos passados.

Nesses séculos que antecederam o advento cristão, além dessa acentuada distinção de gênero, também percebe-se a concepção negativa que se tem da mulher. O pensamento pitagórico (séc. VI a.C) já refletia uma profunda depreciação ao feminino, quando relacionava a mulher a um princípio mau, gerador do caos, da desordem, nivelando-a às trevas. O pensamento aristotélico, por sua vez, não ficou atrás em sua concepção de mulher quando a reduziu a um ser passivo no processo de reprodução humana, concebendo-a como uma espécie de homem incompleto. Todos esses pensamentos e concepções equivocadas atravessaram séculos e imprimiram na história uma inferioridade ao gênero

26 "Ordo podia designar simplesmente o estado de vida de uma pessoa, e ordinare ainda era um termo usado em sua acepção original de proporcionar ordem num sentido político ou metafórico. De fato, ordinare em seu sentido básico indica simplesmente algum método de organização. [...] Por isso, ordines (que é o plural de ordo) pode designar as tarefas que são feitas num certo grupo ou sociedade. É claro que dentro da comunidade cristã havia diferentes tarefas a serem feitas, e essas tarefas eram chamadas, com naturalidade, de ordines, e o processo pelo qual uma pessoa era escolhida para cumprir tal tarefa era chamado de ordinatio". Ver http://www. ihuonline.unisinos.br/index.php?option=com_content\&view=article\&id=2596\&secao $=295$.

27 Entrevista de Phyllis Zagano concedida ao blog Pray Tell, em 6 de outubro de 2015. A tradução é de Moisés Sbardelotto.

Ver http://www.ihu.unisinos.br/noticias/547760-nao-ha-nenhuma-doutrina-contra-as-diaconisas-entrevista-com-phyllis-zagano 
feminino. Na Idade Média, esse pensamento tomou grandes proporções em todos os âmbitos, seja na política, seja na religião e na sociedade, e ainda se arrasta até os nossos dias.

Então, para dirimir uma série de dúvidas e indagações recorrentes sobre a ordenação de mulheres para o episcopado e presbiterado, a Santa Sé, por intermédio da Carta Apostólica Ordinatio Sacerdotalis, do pontífice João Paulo II, veio declarar que a ordenação sacerdotal está reservada somente aos homens. Essa carta apostólica traz em seu conteúdo, a assertiva definitiva em relação à exclusão da mulher ao sacerdócio, quando diz que,

A ordenação sacerdotal, pela qual se transmite a missão, que Cristo confiou aos seus Apóstolos, de ensinar, santificar e governar os fiéis, foi na Igreja Católica, desde o início e sempre, exclusivamente reservada aos homens. [...] Portanto, para que seja excluída qualquer dúvida em assunto da máxima importância, que pertence à própria constituição divina da Igreja, em virtude do meu ministério de confirmar os irmãos [...], declaro que a Igreja não tem absolutamente a faculdade de conferir a ordenação sacerdotal às mulheres, e que esta sentença deve ser considerada como definitiva por todos os fiéis da Igreja (João PAULO II, 1994).

Quando a igreja anuncia não possuir a faculdade de agir perante essa questão, ela está se resguardando na própria Escritura, que foi conservada e aplicada na tradição da igreja desde o início e permanece até hoje. A igreja se declara a guardiã de um tesouro sagrado deixado por Cristo e seus apóstolos, por isso, essa doutrina pertence ao depósito da fé (Fidei Depositum). Para enfatizar o caráter definitivo da impossibilidade da ordenação de mulheres, a igreja lança mão de um documento em "resposta à dúvida sobre a doutrina da Carta Apostólica Ordinatio Sacerdotalis". Neste, a igreja reafirma essa convicção de forma definitiva e irrevogável. ${ }^{28}$

28 Resposta aprovada pelo papa João Paulo II em 28 de outubro de 1995. Ver http://www.vatican. va/roman_curia/congregations/cfaith/documents/rc_con_cfaith_doc_19951028_dubium-ordinatio-sac_po.html 
Existe outro documento da igreja que contém uma lei sobre a ordenação sacerdotal direcionada somente aos homens, trata-se do Codex luris Canonici, isto é, o Código de Direito Canônico. ${ }^{29}$ Esse se apresenta como um documento que legisla, ordena e regula juridicamente a igreja, e que, de certa forma, reforça a exclusão da ordenação de mulheres ao sacerdócio. Nele, "Só o varão baptizado pode receber validamente a sagrada ordenação"..$^{30}$ Com essa investidura, o ministro ordenado age in persona Christi Capitis (na pessoa de Cristo Cabeça), porque "Cristo é a origem de todo sacerdócio" (CNBB, 2000, p. 424) e esposo da igreja (comunidade).

Nesses termos, e acreditamos ser na visão da igreja, pensamos que o sacerdote não seja caracterizado pelo que ele faz, mas sim pelo que ele representa. Se o sacerdote representa Cristo, e Cristo é o esposo da igreja, então temos aqui a união de dois princípios distintos, o masculino e o feminino, um complementando o outro, o que não ocorreria o mesmo, caso fosse uma sacerdotisa, pois que ela representaria uma parte feminina, e sua contraparte que seria a igreja, também feminina. Portanto, nesse pensamento, só os homens poderiam ser esposos da igreja, pois que a "relação entre Cristo e a Igreja é apresentada como vínculo entre o Esposo e a Esposa".31

Ivone Gebara, teóloga e filósofa brasileira, acredita que a questão do sacerdócio feminino é bem mais complexa do que parece. Do seu ponto de vista, seria útil e necessária uma profunda reforma política dentro da igreja católica, ou seja, "uma reforma das teologias que sustentam essas políticas de caráter masculino patriarcal centralizador". Segundo Gebara, essa reforma implicaria uma multiplicidade de

29 "O Código, como principal documento legislativo da Igreja, baseado na herança jurídica e legislativa da Revelação e da Tradição, deve considerar-se o instrumento indispensável para assegurar a ordem tanto na vida individual e social, como na própria actividade da Igreja. Por isso, além de conter os elementos fundamentais da estrutura hierárquica e orgânica da Igreja, estabelecidos pelo seu Divino Fundador ou baseados na tradição apostólica ou na mais antiga tradição, e ainda as principais normas referentes ao exercício do tríplice múnus confiado à própria Igreja, deve o Código definir também as regras e as normas de comportamento". Ver CEP, 1983, p. X-XI.

3o Cânone 1024, Livro IV - Do múnus santificador da Igreja; parte I - Dos sacramentos; capítulo II - Dos ordinandos, p. 180.

${ }^{31}$ Ver João PAULO II, 1988. 
teologias e interpretações, que a seu ver, revelaria a relação "entre a vida ordinária cotidiana e as teologias que sustentam a organização da Igreja nos seus diferentes níveis..$^{32} \mathrm{O}$ pensamento de Gebara apenas alude, de certo modo, para uma atualização e ressignificação da igreja católica diante dos novos tempos, é preciso caminhar lado a lado com a modernização.

Nessa conjuntura de fundamentos teológicos e aspirações por parte da sociedade por uma efetivação e legitimação do sacerdócio feminino, algumas questões emblemáticas nos chamam a atenção, por estarem nas margens desse processo, que é a excomunhão de padres e de algumas mulheres católicas ordenadas sem autorização do Vaticano. Um dos casos se refere ao bispo Rómulo António Braschi, que em 2002 conferiu ordenação sacerdotal a sete mulheres católico-romanas. Em punição a esse ato, o bispo e as sete mulheres foram excomungados da igreja pela Sé Apostólica, por meio de um decreto de excomunhão expedido em 5 de agosto do mesmo ano.33 Outro caso que destacamos, foi a dispensa e posterior excomunhão do padre Roy Bourgeois pela sua congregação ${ }^{34}$ e pelo Vaticano, por ter participado da ordenação de uma mulher no ano de 2008, em Kentucky.

Esses casos refletem um anseio, não apenas por parte de mulheres leigas que acreditam ter essa vocação, mas também por sacerdotes que não veem motivos nem empecilhos teológicos e jurídicos para que elas possam realizar esse desejo. Outra questão bem pertinente que a igreja católica enfrenta é a escassez de padres. O mundo pós-moderno e suas vicissitudes contribuem para uma diminuição considerável de jovens vocacionados aos sacerdócio. Essa realidade poderia favorecer uma postura mais condescendente por parte da igreja, contudo, seu posicionamento permanece inalterado diante dos apelos e desejos por mais inclusão e igualdade de funções.

32 Artigo publicado em 15 de junho de 2016. http://www.padrescasados.org/archives/46388/ ordenacao-de-mulheres-para-qual-igreja-e-com-qual-teologia/

33 Ver: http://www.vatican.va/roman_curia/congregations/cfaith/documents/rc_con_cfaith_ doc_20020805_decreto-scomunica_po.html

34 Catholic Foreign Mission Society of America, também conhecida como Sociedade dos Padres e Irmãos de Maryknoll. 
Nessa realidade e em meio a tantos conflitos, a igreja católica começa a assinalar uma futura inserção feminina, de maneira mais incisiva, no ministério diaconal. Essa questão vem tomando corpo há algum tempo, quando o ainda cardeal Joseph Ratzinger, enquanto prefeito da Congregação para a Doutrina da Fé, confiou à Comissão Teológica Internacional a incumbência de analisar a questão da ordenação de mulheres ao diaconado. A conclusão que essa comissão chegou foi de que a igreja poderia se pronunciar com "autoridade" sobre essa questão, ou seja, que não haveria impedimento, do ponto de vista histórico-teológico, quanto à ordenação de diaconisas. ${ }^{35}$

Frente aos novos tempos e por meio do atual pontificado, uma nova teologia da mulher poderá se desenhar no futuro. Evidentemente que, diante de tantas resistências em relação à modernização e renovação da própria igreja por parte da ala conservadora, o papa Francisco encontra fôlego para propor a formação de uma comissão mista para o estudo e viabilização do diaconado feminino. Em agosto de 2016, essa comissão oficial foi constituída com um presidente e doze integrantes leigos e religiosos (seis homens e seis mulheres), para estudar essa questão, sinalizando, assim, uma maior abertura quanto à participação feminina na vida da igreja. ${ }^{36} \mathrm{Um}$ dos membros mais progressistas dessa comissão é a teóloga Phyllis Zagano, da Universidade de Hofstra (EUA). A mesma é autora de muitos livros e artigos que tratam das mulheres diaconisas, entre eles, Women Deacons?: Essays with Answers (Liturgical Press, 2016).

Se a igreja fundamenta sua decisão de não ordenar mulheres sacerdotisas na sua escritura, nessa mesma escritura também se fundamentam aqueles que são a favor do sacerdócio feminino. Na realidade, são duas faces de uma mesma moeda. Os que defendem esse grande passo dentro da igreja, citam alguns trechos bíblicos, entre os quais está um deles em Atos dos Apóstolos (At 11, 5-9) onde Pedro tem uma visão de animais impuros, e Deus ordena que ele os mate e os coma.

\footnotetext{
35 Ver artigo de William T. Ditewig. Disponível em: https://pt.aleteia.org/2016/05/13/as-diaconisas-e-o-papa-francisco/

36 Ver: http://br.radiovaticana.va/news/2016/08/02/papa_institui_comiss\%C3\%A30_sobre_o_diaconato_das_mulheres/1248757
} 
Nessa interpretação da escritura, cabe ao Espírito Santo a condução da "Igreja por novas e radicais estradas, derrubando leis antigas para abraçar novas liberdades". ${ }^{37}$ Como um exemplo bem peculiar e inserido no cristianismo, citamos aqui a Igreja Anglicana e a Igreja Episcopal ${ }^{38}$ dos Estados Unidos, que abraçaram e oficializaram a ordenação sacerdotal feminina, viabilizada por meio de muitos debates e reflexões. ${ }^{39}$ Essa ordenação episcopal e presbiteral de mulheres viria a ser aprovada em 1992 e dois anos mais tarde, em 1994, aconteceriam as primeiras ordenações. Notemos que foram ordenadas não somente sacerdotisas, mas também bispas. Um grande avanço da igreja reformada.

\section{CONSIDERAÇÕES FINAIS}

Se formos analisar profundamente a situação e o papel da mulher dentro da igreja católica, verificaremos que não houve avanços significativos, ou seja, espaço algum foi dado além do que já existia. O que temos no momento são apenas sinalizações, as quais apontam para uma moderada inserção feminina na igreja por meio do diaconado, já que para a sua ordenação sacerdotal, as portas estão fechadas em caráter definitivo, pela carta apostólica Ordinatio Sacerdotalis. A igreja católica reconhece a importância e o papel que a mulher vem desempenhando na história do cristianismo, contudo, ela não abre brechas para uma possível reflexão e discussão sobre o tema.

Podemos pensar que seria justo tal ordenação ministerial, pois colocaria a mulher numa posição de igualdade com o homem, pois apesar de serem iguais em dignidade conforme a doutrina, na prática, a mulher

37 Ver artigo de Dwight Longenecker. Disponível em: https://pt.aleteia.org/2013/12/24/sacerdotisas-catolicas-uma-possibilidade/

38 Fora do território da Inglaterra, principalmente nos EUA ou nos países latinos, usa-se a denominação "episcopal”. As duas são igrejas irmãs.

39 De orientação católico-protestante, o cristianismo inglês (anglicano ou episcopal), de modo diferente do romano, deu continuidade às ordenações diaconais femininas, cujas práticas, como já vimos, está na raiz religiosa da igreja primitiva, e se estenderam até o medievo (séc. XIII). Apesar do anglicanismo ser derivado da igreja reformada (reforma protestante e reforma inglesa), alguns ramos da igreja anglicana ainda mantiveram, em certa medida, essas práticas rituais da igreja que o gestou. Como diz Mendonça (2008, p. 157), “A reforma da Igreja da Inglaterra, todavia, foi conservadora, porque manteve o velho sistema de governo da igreja e muitas das antigas formas de culto". 
continua numa escravidão historicizante. Mesmo com toda performance feminina ao longo do tempo, poucas foram as conquistas no âmbito religioso. Maria Madalena, aquela que foi a apóstola portadora da boa nova e que poderia representar todas as mulheres que almejam uma função sacerdotal na igreja, parece não passar de uma santa com um dia do ano dedicado em sua memória.

De qualquer forma, devemos ser otimistas, mesmo diante da negação religiosa no tocante à ordenação sacerdotal feminina. $O$ universo religioso católico romano é apenas um pequeno reflexo de uma realidade social desigual ainda maior. Como é sabido, a história humana e religiosa foi e ainda é profundamente marcada pela discriminação à mulher, sendo portanto, necessários ainda muitos embates e inquirições até finalmente ter o seu papel reconhecido e o seu espaço efetivado dentro da igreja. Nesse tocante, temos à frente grandes teólogas dispostas a lutar pela busca da inserção feminina no âmbito da igreja, a exemplo de Zagano e Ruether, já citadas.

Parece-nos apropriado o pensamento de Simone de Beauvoir, quando se reporta à condição de segundo sexo, inequivocamente atribuído à mulher. Nesse sentido, “[...] A mulher determina-se e diferencia-se em relação ao homem e não este em relação a ela; a fêmea é o inessencial perante o essencial. O homem é o Sujeito, o Absoluto; ela é o Outro" (Simone de BEAUVOIR, 1970, p. 10). São estigmas e amarras que foram colocadas na mulher no percurso da história humana, cabendo a ela participar de um processo moderno de superação hercúlea em busca de sua verdadeira essência e liberdade.

\section{REFERÊNCIAS}

BEAUNE, Colette. Joana D’Arc. Tradução de Marcos Flamínio Peres. São Paulo: Globo, 2006.

BEAUVOIR, Simone de. O segundo sexo. Tradução de Sérgio Milliet, 4. ed. São Paulo: Difusão Europeia do Livro, 1970.

BLÁZQUEZ, José María. El cristianismo hispano: su origen y repercusión en la sociedad hispana y en la iglesia universal. Madrid: Colegio Libre de Eméritos, 2010. Disponível em: <http://www.colegiodeemeritos.es/docs/repositorio/es_ES/conf_1_blazquez_el_cristianismo_hispano.pdf>. Acesso em: 15 abr. 2017. 
BULFINCH, Thomas. O livro de ouro da mitologia: Histórias de deuses e heróis. Tradução de David Jardim. Rio de Janeiro: Ediouro, 2006.

CEP. Código de Direito Canônico, 4. ed. Lisboa: SNAO, 1983.

CNBB. Bíblia Sagrada. Edição Pastoral. São Paulo: Paulus, 1990.

. Catecismo da Igreja Católica. Edição Típica Vaticana. São Paulo: Loyola, 2000. CONGREGAÇÃO PARA A DOUTRINA DA FÉ. Declaração Inter Insigniores sobre a questão da admissão das mulheres ao sacerdócio ministerial, 1976. Disponível em: <http://www. vatican.va/roman_curia/congregations/cfaith/documents/rc_con_cfaith_doc_19761015_ inter-insigniores_po.html>. Acesso em: 25 mar. 2017.

. Resposta à dúvida sobre a doutrina da Carta Apostólica Ordinatio Sacerdotalis, 1995. Disponível em: <http://www.vatican.va/roman_curia/congregations/cfaith/ documents/rc_con_cfaith_doc_19951028_dubium-ordinatio-sac_po.html>. Acesso em: 16 mar. 2017.

. Decreto de excomunhão, 2002. Disponível em: <http://www.vatican.va/ roman_curia/congregations/cfaith/documents/rc_con_cfaith_doc_20020805_decreto-scomunica_po.html>. Acesso em: 21 abr. 2017.

DITEWIG, William T. As diaconisas e o Papa Francisco, 2016. Disponível em: <https:// pt.aleteia.org/2016/05/13/as-diaconisas-e-o-papa-francisco/>. Acesso em: 21 abr. 2017.

DRIOTON, É; CONTENAU, G; DUCHESNE-GUILLEMIN, J. As religiões do antigo oriente. Tradução de Valeriano de Oliveira. São Paulo: Flamboyant, 1958.

ELIADE, Mircea. O sagrado e o profano: a essência das religiões. Tradução de Rogério Fernandes, 3. ed. São Paulo: Martins Fontes, 2010.

GEBARA, Ivone. Ordenação de mulheres? Para qual Igreja e com qual teologia? 2016. Disponível em: <http://www.padrescasados.org/archives/46388/ordenacao-de-mulheres-para-qual-igreja-e-com-qual-teologia/>. Acesso em: 18 mai. 2017.

INSTITUTO HUMANITAS UNISINOS. O surpreendente debate sobre as sacerdotisas católicas (sobre o editorial do Jornal National Catholic Reporter), 2012. Disponível em: <http://www.ihu.unisinos.br/noticias/516324>. Acesso em: 10 fev. 2017.

JOÃO PAULO II, Papa. Carta Apostólica Mulieris Dignitatem, 1988. Disponível em: <http://w2.vatican.va/content/john-paul-ii/pt/apost_letters/1988/documents/hf_jp-ii_apl_19880815_mulieris-dignitatem.html>. Acesso em: 23 mar. 2017.

. Carta Apostólica Ordinatio Sacerdotalis, 1994. Disponível em: <https:// w2.vatican.va/content/john-paul-ii/pt/apost_letters/1994/documents/hf_jp-ii apl_19940522_ordinatio-sacerdotalis.html>. Acesso em: 24 mar. 2017.

JUNGES, MÁRCIA. A Igreja deveria cogitar o retorno da ordenação das mulheres. Revista do Instituto Humanitas Unisinos, Rio Grande do Sul, n. 295, 2009. Disponível em: <http://www.ihuonline.unisinos.br/index.php?option=com_content\&view=article\&id=2 596\&secao=295>. Acesso em: 14 abr. 2017. 
KAUTSKY, Karl. A origem do cristianismo. Tradução de Luiz Alberto Moniz Bandeira, 2. ed. Rio de Janeiro: Civilização Brasileira, 2014.

LONGENECKER, Dwight. Sacerdotisas católicas: uma possibilidade? 2013. Disponível em: <https://pt.aleteia.org/2013/12/24/sacerdotisas-catolicas-uma-possibilidade/>. Acesso em: 6 mar. 2017.

MENDONÇA, Antônio Gouvêa. Protestantes, pentecostais e ecumênicos, 2 ed. São Bernardo do Campo: Universidade Metodista de São Paulo, 2008.

PONTIFÍCIA COMISSÃO BÍBLICA. Perfil. Disponível em: <http://www.vatican.va/roman_curia/congregations/cfaith/pcb_documents/rc_con_cfaith_pro_14071997_pcbible_po.html>. Acesso em: 02 abr. 2017.

POTESTÁ, Gian Luca; VIAN, Giovanni. História do Cristianismo. Tradução de Orlando Soares Moreira. São Paulo: Edições Loyola, 2013.

RADIO VATICANA. Comissão sobre o diaconato das mulheres, 2016. Disponível em: <http://br.radiovaticana.va/news/2016/08/02/papa_institui_comiss\%C3\%A30_sobre_o_diaconato_das_mulheres/1248757>. Acesso em: 14 fev. 2017.

RYAN, Penelope J. Católico praticante: a busca de um catolicismo para o terceiro milênio. São Paulo: Loyola, 1999.

RUETHER, Rosemary R. Sexism and God-Talk: Toward a Feminist Theology. Boston: Beacon Press, 1983. Disponível em: < https://www.questia.com/read/23189059/sexism-and-god-talk-toward-a-feminist-theology>. Acesso em: $1^{\circ}$ dez. 2017.

SCAPI, Paolo. Politeísmos: as religiões do mundo antigo. Tradução de Camila Kintzel. São Paulo: Hedra, 2004.

Submetido em: 11-9-2017

Aceito em: 5-12-2017

Mandrágora, v.23. n. 2, 2017, p. 5-25 